\title{
The Adriatic: A European Region of the Future?
}

\author{
Milan BUFon, Koper/Capodistria*
}

\section{Content}

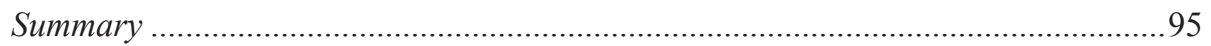

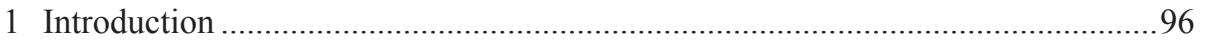

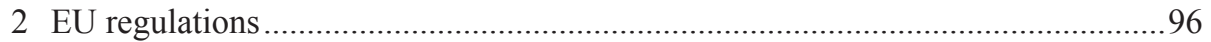

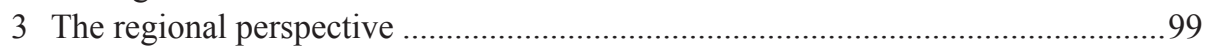

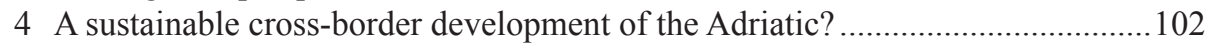

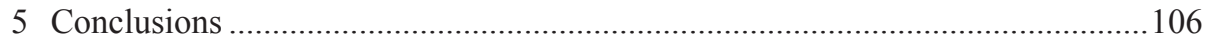

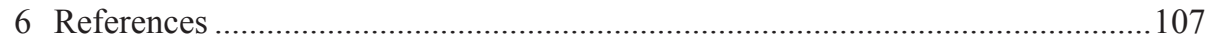

\section{Summary}

The paper will discuss the development opportunities of the Adriatic as a European region of the future. It will also present some issues related to the difficult implementation of an integrated cross-border development vision within the EU, in particular for what the 'multi-level'governance is concerned. The main related issues in the Adriatic embrace the difficult creation of European Groupings of Territorial Cooperation (EGTCS), the implementation of the so-called Espoo Convention and the Euro-Mediterranean Partnership (EUROMED) perspective for an integrated coastal and regional management, within which the Adriatic could represent a special development priority for the European Union (EU) as the Baltic region within the socalled Northern Dimension. The paper will show how the discussed case study opens the need for a more appropriate governance of different horizontal (spatial and sectorial) as well as vertical (hierarchical) policies in planning cross-border cooperation or social and spatial (re)integration of borderlands and population, especially if we try to create a more sustainable and 'long-lasting' development plan for our increasingly globalised and co-dependent future European 'common home'.

* Milan Bufon, Professor, PhD., Department of Geography, Institute for Social Studies, University of Primorska, Titov trg 4, SI-6000 Koper/Capodistria, Slovenia;

email: milan.bufon@upr.si 


\section{Introduction}

The problems related to sustainable development planning in Europe are connected with the problem of cross-border, i.e. inter-state and inter-regional cooperation and adopting joint development programmes within the framework of a supra-state system like for instance the European Union (EU). In this area, the EU has adopted many initiatives, which would bring more harmonised forms of social and spatial planning in the European region. On the local level, the Interreg programme has been evolving for a longer period, and now includes all 'internal' and 'external' borderlands of the EU member states. For the purpose of improving the coordination of cross-border initiatives and projects, the European Commission in 2004 proposed the establishment of permanent cooperation bodies that would on the one hand enable a more structured implementation of Article 159 of the Treaty of the European Community regarding internal economic and social cohesion, including the redistribution of a part of the EU budget to its less-developed regions, and on the other hand introduce a new legal order in the European practice, which would take the 'governance' of cross-border regions and the so-called Euroregions out of the exclusive jurisdiction of national sovereignty and thus enable them to communicate closer and more directly with the European development authorities in Brussels (Sсотт 2006). Due to this 'dual' character, the initiative faces all problems, typical of the contradictory search for balance between convergence and divergence that constantly follows the process of European integration. Consequently, we face many different interpretations of the function and nature of Euroregions: under this term, some understand only a combination of two or several borderlands that are instrumentally connected only by the wish for receiving European subsidies from the Interreg programme; others believe that these are institutional bodies that have to establish certain joint bodies for joint management of their development programmes; another opinion is that Euroregions are not only co-dependent areas in socio-economic terms, but that they are also socio-culturally linked by a joint regional affiliation (BUFON 2011a). The article will present some issues related to the difficult implementation of an integrated cross-border development vision in Europe, based on the case of the Adriatic region.

\section{EU regulations}

EU Regulation No. 1082 from 2006 based on the Commission's proposal for closer cross-border cooperation clearly reflects the compromise between regional aspirations and state control. It offered the possibility for forming the European Grouping of Territorial Cooperation (EGTC) not only to border, but also to other European regions seeking to develop interregional cooperation and planning, but at the same time it specified that EGTCs are submitted to the decisions of national 
central bodies (LANGER 2007). The difficult enforcement of the European 'multi-level' governance system is also shown in the field of wider spatial planning and verification of its environmental and cross-border impacts. An additional problem here are the different legal aspects of social and spatial 'co-governance' of cross-border areas and cross-border projects, or the relations between the classic, centralistic (national), and the new 'European' planning system, which is quite more 'democratic', but also more complex and time-consuming, since the decision-making process also includes the public and local community, interested in individual projects, and requires in addition an appropriate inter-state and cross-border agreement in all those cases when plans could provide cross-border impacts (MACRORY \& TURNER 2003).

This issue was first addressed by the European Community in 1987 within the scope of implementing the Environmental Action Programme, recommending in this context a greater participation of the 'public' and 'local' actors in the planning process. The same recommendations were emphasised by the Rio Declaration of the UN Conference on Environment and Development (UNCED) of 1992. The EU member states were also guided in this direction by the Treaty of Amsterdam of 1997, which on the basis of the 'subsidiarity' principle recommended that all decisions are taken as closely as possible to the citizens of the Union. Otherwise, the European Commission (EC) regulative of 1985 demanded from member states that in case of interventions with possible cross-border environmental impacts all necessary information on the project should be given to involved neighbouring countries and their opinions considered in the process of implementing the project. This directive was followed by the EC Convention on Environmental Impact Assessment in a Transboundary Context (the so called Espoo Convention), which was operationalised mostly by the EU Directive of 1997. The latter demands from member states to provide to the interested local public on both sides of the border all the information related to projects with expected crossborder impact. In this way, the procedure of planning interventions with cross-border impact actually includes local community administrations as well as neighbouring countries or neighbouring local administrations.

By stimulating a higher and more intense form of inter-state cooperation, the EU has started to evolve own, 'communitarian' development and spatial policies, in particular in the field of urban systems, urban-rural relationships, infrastructural systems, and preservation of natural and cultural heritage. Such a 'common' policy would improve measures designed for the achievement of the general EU goals related to a 'sustainable' development and the 'unity in diversity' paradigm. These development visions do not consider national borders as the usual limit for traditional planning, thus they strive to strengthen internal cohesion in the EU area by stimulating pan-European projects. A clear result of joint planning efforts is the European Spatial Development Perspective (ESDP) of 1999, within which the planning of the so-called trans-European transport network (TEN-T) as well as the planning of joint development visions in wider regional contexts like the Baltic Region, the Atlantic Arc and the Mediterranean 
Region (EUROMED) have evolved. In the 2007-2013 financial period, 8 bn $€$ were intended for targeting European territorial cooperation, which are allocated to as many as 53 different cross-border cooperation programmes (which accounts for $74 \%$ of total funding) and 13 areas of transnational and interregional cooperation (which accounts for the remaining $26 \%$ of total funding). A general extended cooperation planning programme is then the European Observation Network for Territorial Development and Cohesion programme (ESPON), providing grounds and funds for bottom-up and regional-based shared development initiatives. In the recent period, transport- and environment-related issues on the EU level have been linked to energy-related issues, mostly in the area of supplying and distributing energy products. In this case, no particular joint strategy could be noticed, although on the level of regional connections within the EU, we can notice that in some areas certain progresses in developing more coordinated planning have been achieved (BuFON 2011b).

This is also the case of a more coordinated governance of coastal areas in the Mediterranean Region, according to the EU Commission's Directive from 2010, which refers to the Barcelona Convention of 1976 for the Protection of the Marine Environment and the Coastal Region of the Mediterranean, and the Protocol on Integrated Coastal Zone Management in the Mediterranean, which was also adopted by the EU Council in 2008. The Directive warns about the increasing urban pressure of coastal zones in the region, since approximately $40 \%$ of the coastline are already built and this percentage will presumably be increased to $50 \%$ by the year 2025 . Urbanisation, marine transport communication (mostly due to the transport of energy products) and environmental problems arising from this, demand, according to the EU Commission's opinion, an integrated governance of coastal zones, as was already established by the UN Mediterranean Commission on Sustainable Development at its meetings in Tunis in 1997, Monaco in 2001, Catania (Italy) in 2003, and Portorož/Portorose (Slovenia) in 2005. Article 6 of the 2010 Directive among other matters requires the application of an ecosystem-related approach in planning and governing coastal zones; the inclusion of an interested local communities and non-governmental organisations in the decisionmaking process; horizontal coordination among governmental sectors, and vertical coordination among governmental and local administrations with interventions in coastal zones that should not lead to excessive urbanisation, but contribute to decreasing or eliminating the possible negative environmental impacts. For this purpose, Article 28 of the Directive encourages cross-border cooperation in the field of exchanging all information prior to adopting plans or interventions causing negative impacts on coastal zones of neighbouring countries and the necessary coordination of views and plans, as well as by adopting bilateral or multilateral agreements (EC 2010). 


\section{The regional perspective}

Recent experiences of some cross-border coastal zones in Europe are quite encouraging, for instance in the case of developing joint marine environment protection policies (e.g. the formation of the International Marine Park between Corsica [Corse/ Corsica] and Sardinia [Sardegna/Sardigna]), in the preservation of environmental and promoting tourism potentials of the coastal zone (e.g. the Integrated Project of Coastal Zone Management along the French-Italian border), in evolving transport and information flow and joint policies for decreasing the hazards of pollution and accidents at sea (e.g. between the United Kingdom and France in the Channel area). But the most complete and intense cross-border cooperation has been established in the region of the Baltic Sea (Sсотт 2003). This cooperation enables some former 'Eastern' countries to make close contacts with the 'Western' European region, thus accessing the EU more rapidly, and, in addition, it strengthens the role of Nordic countries within the EU. The EU thus recognises this region a special development priority (the so-called Northern Dimension), allocating to it additional financial funds. The management of joint issues progresses on several levels: the main body is the Council of the Baltic Sea States, which includes the representatives of the EU as well as the representatives of the Danish, Estonian, Finnish, Icelandic, Latvian, Lithuanian, German, Norwegian, Polish and Russian governments; other institutions are the Baltic Marine Environment Protection Commission, the Union of the Baltic Cities, the Baltic Sea Chambers of Commerce Association and the Baltic Sea States Sub-regional Cooperation, which connects sub-state administrative units in the region. The beginnings of regional cooperation date back to the 1980s, however, major progress was noticed only after 1992, when the joint Committee on Spatial Development in the Baltic Sea Region was established, and was later on transformed into a development forum named the Baltic Bridge. The latter has set four priority goals and working groups connected to these goals: (1) formation of strategic regional governance for cross-border cooperation in the field of sustainable spatial development; (2) development of the urban network for a more coordinated settlement policy; (3) improvement and strengthening of the communication and transport system; (4) encouraging sustainable development in rural areas. A special, EU-supported project within the Community's framework is the Via Baltica, the transport axis on the Tampere-Helsinki/Helsingfors-Tallinn-Riga [Rīga] route, extended to Warsaw [Warszawa] and Berlin, which was already under realisation in 1998. This route would also be connected with the so-called TEN-T IA Corridor between Hamburg and Kaliningrad (PARTEKA 2006).

Despite the progress of cross-border regional cooperation in the previously divided Baltic Sea region, unfortunately, a certain extent of regression has to be noted in the Northern Adriatic region. Here, the Alps-Adriatic Working Community emerged as soon as in 1978, and connected regions of southern Germany, northern 
Italy, Austria, western Hungary, as well as Slovenia and Croatia as republics of the former Yugoslavia. Until the 1990s, this was the only 'Euroregion' established across the Iron Curtain that geopolitically divided the European 'West' and 'East'. It still exists (without Bavaria [Bayern]), but lost a great part of its potentials, even though closer cooperation was mostly initiated and conducted in the narrower part of this Community, including Slovenia, Friuli-Venezia Giulia in Italy and Carinthia [Kärnten] in Austria (the so-called Three-borders region). In fact, after 1990, only Carinthia expressed more interest for the Community, hosting the Alps-Adriatic General Secretariat in Klagenfurt, whilst the common management is still performed according to the member rotation principle (VALENTIN 2007). In the past few years, we can notice an increased cooperation between the Italian regions Veneto and Friuli-Venezia Giulia and the Austrian region Carinthia, aiming to establish a new 'Euroregion' to replace the 'old' Alps-Adriatic Working Community, also in the sense of rising common transport interests related to the Baltic-Adriatic corridor, which has been established as one of the priority EU development axes within the TEN-T programme. Slovenia is currently excluded from this new regional cooperation, since on the EU level it operates as a rather centralised country-region. Therefore, it has more problems in the process of including into the system of sub-state European cooperation or does not show much interest for such cooperation (BUFON 2008).

Anyhow, it is expected that the Adriatic region will become more central in the European development and planning context after Croatia has entered the EU in July 2013 (Bufon 2012). This situation will also improve regional cross-border cooperation in the area, as Croatia, in contrast to Slovenia, is already divided in substate administrative units (regions), and they are also intensifying their integration in the European system of inter-regional cooperation. In this regard, some new opportunities will certainly be given by the development of the new Adriatic-Ionian cohesion region within the European Territorial Co-operation Programme 2014-2020. A strategy document for this region was launched by the EU Commission in June 2014. The Strategy will also provide a valuable opportunity for would-be members and candidates of the EU to work alongside EU members, in particular contributing to the integration of the Western Balkans into the European Union. This is the first EU 'macroregional strategy' with such a large proportion of non-EU countries (Albania, Bosnia and Herzegovina, Montenegro and Serbia) cooperating with EU members (Croatia, Greece, Italy, and Slovenia). The Strategy mainly revolves around the opportunities of the maritime economy - 'blue growth', land-sea transport, energy connectivity, protecting the environment and sustainable tourism - sectors that are bound to play a crucial role in creating jobs and boosting economic growth in the region. The starting point for this is the Maritime Strategy for the Adriatic and Ionian Seas, adopted by the Commission on 30 November 2012 and now incorporated into the Strategy.

Additional possibilities for a 'common' development planning in the North Adriatic region were brought in the past by the bilateral agreements between Italy and 
former Yugoslavia, which in 1955 largely liberalised the local cross-border movement of persons and trade, also by forming a special bilateral commission that regularly monitored and directed the implementation of this agreement. In this way, close cross-border functional ties could develop, exceeding in many views the intensity of cross-border contacts and exchanges along other 'Western' borders. Thus the current Slovenian-Italian border has also become known in the wider European context as the "most open" border between the 'West' and the 'East' of that time (KLEMENČIČ \& Bufon 1991). The local agreement was followed by a new inter-state treaty in 1976, based on which a mixed Italian-Yugoslav chamber of commerce, and a joint committee for water economy issues and water regimes regulation were established. This treaty was also premised on the assumption that a customs-free industrial zone will emerge on the border between Italy and today's Slovenia nearby the city of Trieste, and that a joint fishing zone will be established in the Gulf of Trieste. Both projects have not been realised, partly due to the resistance of the citizens of Trieste to a greater cooperation with the neighbouring country, and partly due to the insufficient interest of both neighbouring countries for an increased integration of their border areas.

Similar discrepancies emerged on the municipal level, where the border urban municipalities of Gorizia and Nova Gorica - divided by the state border in 1947 in two asymmetrical, but complementary parts - in the 1987-1991 period also agreed on mutual harmonisation of urban and spatial plans, the common management of the motorway truck border terminal with related customs-free zones, the introduction of a joint city bus circular route, the preparation of joint cultural events, the introduction of the language of the neighbouring country in second level school education programmes and other initiatives.

It is surprising that the contents of these and similar agreements have remained mostly unrealised even today, despite the fact that Slovenia got its independence in 1991, joined the EU in 2004 and in 2007/08 entered both the Schengen area (which led to the elimination of all border controls with other EU member states) and the Euro zone. It seems as the break-up of Yugoslavia caused the deviation of a wider European and bilateral interest from the policies of cross-border cooperation in the Adriatic region, since all bilateral committees, which dealt with this issue, stopped operating at that time. Italy and Slovenia appear to be quite satisfied with the general systemic cooperation, provided by the common membership in the EU. However, they did not preserve or develop any additional instruments of cross-border cooperation and integration on an interstate or local level, such as they are now being enforced by other EU countries along their 'internal' and 'external' borders (BUFON 2009).

Along with slowly progressing cross-border cooperation and integration policies between Italy and Slovenia, neighbouring relations between Slovenia and Croatia also started to deteriorate significantly, mostly due to border disputes. Not earlier than in 2011, also due to the pressure put by the EU, the states came to an agreement to eventually resolve the dispute with the help of an international arbitration, clearly 
showing the failure or even the lack of problem-solving oriented bilateral agreements and approaches in this area. Although the functional cooperation on the local population level in the Northern Adriatic region has increased despite the lack of institutional forms of cross-border integration, thus leading to the formation of a 'spontaneous' codependable area in the field of labour, supply, personal services and leisure, which partly includes the Croatian area, separate state development policies cause more conflict or competitiveness-based situations rather than provide integration opportunities, thus hindering the great development potential of this area (BuFON \& MinGHi 2000).

\section{A sustainable cross-border development of the Adriatic?}

This is especially noticeable in the lack of joint governance of coastal zones, as can be seen from the cases of the separate development of the ports in Trieste and Koper/Capodistria, and the planned construction of gas terminals in the Gulf of Trieste. There is only slightly more than $10 \mathrm{~km}$ air line between Koper/Capodistria and Trieste, but their development policies are very different. During the Republic of Venice, Koper/Capodistria was one of the largest marine centres of the eastern part of the Adriatic Sea, but after the downfall of this state and after the accession of western Istria [Istra] to the Austrian Monarchy in the beginning of the $19^{\text {th }}$ century, Trieste and Rijeka began developing as the main ports for the Austrian and Hungarian parts of the Monarchy. In the passage from the $19^{\text {th }}$ to the $20^{\text {th }}$ century, Trieste's population increased considerably (from 80,000 in 1850 to 220,000 before World War I), thus evolving to one of the largest ports in the Mediterranean (from approximately 250,000 tons of cargo handling in 1850 to about 3.5 million tons at the end of the Austrian era). Only after the new delimitation between Italy and Yugoslavia, originating from World War II, Koper/Capodistria took over the 'new' role of being the centre of south-western Slovenia and the main port of this Yugoslav republic, even though the traffic remained poor: in 1962, cargo handling amounted to only 300,000 tons, and in 1966, when the railway connection with Koper/Capodistria was built, cargo handling increased to approximately 800,000 tons. In the time of Yugoslavia, the port of Koper/ Capodistria was specialised mostly for the import of tropical fruits from the south and east Mediterranean, as well as other products, also for transit transport to Czechia and Hungary on the one hand, and south Germany and Austria on the other. In the 1970s the import of oil and oil derivatives increased, and container transport gained in importance in the 1980s, when transitory transport to Austria had strengthened. The latter had concluded a preferential agreement with the port in Trieste, however, the port in Koper/Capodistria gained in importance in Central Europe mostly due to competitive prices and better reliability of delivery (BuFON 2003). 
Otherwise, the transport in the port of Koper/Capodistria strongly increased after Slovenia's independence, when the cargo handling increased by $8 \%$ on an annual level and exceeded 9 million tons in 2000, achieved 18 million tons in 2013, while in the same period cargo handling in the port of Trieste, which in 2013 became the largest port in Italy according to total cargo transport, increased in the same time to approximately 55 million tons. We should also mention that about $75 \%$ of total cargo handling in the port of Trieste is related to the import of oil for the pipeline running to south Germany and Austria, and that according to the actual commerce, Koper/Capodistria has actually achieved better results than Trieste. This can be seen mostly in the large increase of handled containers, where in 2013 Koper/Capodistria achieved 600,000 TEU (in 2000 it figured only slightly less than 100,000 TEU of cargo handling), while Trieste and Venice [Venezia] at the same time managed each only approximately 450,000 TEU of cargo handling.

On the other hand, a certain 'specialisation' of ports has been occurring in the Northern Adriatic region: along with the oil terminal (40\% of total 25 million tons cargo handling), Venice develops mostly passenger tourist transport and track ferry cargo (Ro-Ro) to Greece and Turkey, which is also typical for the port of Trieste, remaining also the main Adriatic oil terminal (over 40 million tons), while the port in Koper/Capodistria is establishing itself in the field of container transport, and also vehicle handling between Europe and Asia (over 450,000 vehicles).

The increasing globalisation of traffic flows, the integration of transport systems on the EU level and the increased 'internal' competition among the leading ports of the North Sea and the peripheral ports in the Mediterranean somehow 'forced' the ports of the Adriatic Sea to start making agreements on joint emergence on the external markets. In 2009, the ports in Koper/Capodistria, Trieste, Venice and Ravenna formed the North Adriatic Port Association (NAPA), which has been also joined by the port of Rijeka in 2013. This system of ports consists of approximately 125 million tons of cargo handling and takes the fourth place on the European level following the Rotterdam-Antwerp [Antwerpen] and Hamburg port system (a total of 600 million tons) and Hamburg (approximately 130 million tons). In this way, the NAPA system wants to establish itself within the EU as a significant player in the Marine Highways programme, according to which a part of the road track transport would be redirected to the sea, thus disburdening the overloaded European highway network and reducing $\mathrm{CO}_{2}$ emissions. Similarly, the association wishes to establish its own 'sustainable' character in relation to global transport ways, therefore, it is now promoted as the "green way to Europe", mostly in the relation to the rapidly increasing Asian market, since the transport distance between the Korean peninsula and north-European ports is about $21,500 \mathrm{~km}$, but only approximately $17,500 \mathrm{~km}$ to the ports of the Upper Adriatic Sea. This would enable savings in time - approximately five days ride (in case of navigation between Hong Kong [Xianggang] and Hamburg) - and also 12\% reduction of $\mathrm{CO}_{2}$ emissions. Due to these motives it is prospected that in the following years, 
marine commerce of the Mediterranean ports will, for the first time in modern history, overrun the commerce in North Sea ports, and the current 'peripheral' Adriatic ports will reinforce themselves in the revitalisation of the 'old' marine communications between Europe and the 'Orient'.

This development will also demand more intensive inter-state and local cooperation in the area of transport, spatial and environmental planning. This goal, however, is quite remote, which is proven by the uncoordinated line of the main European transport axes TEN-T across the region, as we can see in the case of the Corridor $\mathrm{V}$ on the Milan [Milano]-Budapest route, where harmonisations took quite a long time due to the problem of accessing Trieste and Koper/Capodistria on the anticipated new railway route, or in the case of the not yet completely defined BalticAdriatic Corridor, where three different versions of crossing the Alps are possible, namely right after Innsbruck (which would advantage the port of Venice), right after Villach (which would advantage the port of Trieste), or right after Ljubljana (which would advantage the port of Koper/Capodistria). To solve the issue, the European Commission has suggested all parties to improve inter-state and inter-regional cooperation, and especially to improve transport and planning cooperation between Trieste and Koper/Capodistria, which would enable a joint and coordinated accession of both main North Adriatic ports to the European development axes.

But cooperation is often replaced by potential conflict also in other areas, where joint planning would be required, for instance in the planning of gas terminals, which the Italian government wanted to place in the Gulf of Trieste. The supply of energy resources, especially natural gas, is quite important for Italy, since it does not produce enough energy resources by itself and thus significantly depends on the Russian and Algerian suppliers via the existing pipelines. By developing the gas terminal system, the state would have access to cheaper gas on the 'free' market, which would be delivered by special boats for the transport of liquefied gas. Therefore, Italy planned to build six liquefied natural gas (LNG) terminals. The first one and the only one until today was built in 2009 on a platform approximately $15 \mathrm{~km}$ from the coast near Rovigo, with the capacity of 8 billion $\mathrm{m}^{3}$ of gas per year (mostly from Kuwait), covering approximately $10 \%$ of the Italian consumption.

It was initially planned that two gas terminals would be built near Trieste: one on the platform, the second one on land. This plan was rejected by the interested local administrations, and the Republic of Slovenia also questioned this issue, which would have to be harmonised with the Italian side because of the expected crossborder impact, in accordance with the provisions of the Espoo Convention. In 2007, the administration of the Friuli-Venezia Giulia region also intervened in the procedure and confirmed the construction of one terminal. This caused a procedural conflict in the framework of the 'traditional' state-based procedure, since the Italian legislation determines that regional governments should make the final decisions regarding such 
interventions, although their realisation in practice strongly depends on the local (municipal) level and its spatial and development plans. But in this case, the procedure was actually handled by the central government, because in the Italian system it has an exclusive competence in international coordination with neighbouring countries due to the cross-border dimension of the project.

Such a confused situation prolonged considerably the decision-making administrative procedure, which in the case of this particular project was expected to be implemented by the year 2013. Experts have also expressed many doubts about the project, since the terminal would be integrated in a very shallow Gulf of Trieste (depth up to $20 \mathrm{~m}$ ) with low water mass and limited water flow, which thus cools quite significantly during winter, disabling permanent and sufficient energy for repetitive gasification of liquefied (frozen) gas. Contrary to this, the object - for the purposes of which an additional gas pipeline with the capacity of 165 billion litres of gas per week should be built across the entire Gulf of Trieste sea bottom - would contribute to further excessive cooling of the sea and endangering marine biodiversity, it would negatively impact traditional fishing and tourism activities. In addition, environmentalists are also concerned about security, considering that the gas plant would be located near a very densely inhabited coastal zone.

When the Italian Government in 2009 confirmed the plan, Slovenia as well as the Alps-Adriatic Green international ecological movement announced a protest at the European Court, and local municipalities announced that they would file a legal action at the Italian Administrative Court. Since the European administration offices found numerous deficiencies in the project proposal, the investor (the Spanish group Gas Natural) announced a new project for the year 2010 (but actually presented it only in 2011), while bilateral talks between Italy and Slovenia tried to integrate the terminal project, rather than in a wider strategy of integrated cooperation, in a system of inter-state "transactions": the Italian side proposed to Slovenia to accept the project in exchange for better inclusion of Koper /Capodistria in European transport corridors, and the Italian co-participation in the eventual construction of a new thermonuclear plant in Slovenia.

Also in 2010 the situation further complicated, since the Slovenian government started thinking about setting up a 'competitive' terminal near Koper/Capodistria (although the Municipality of Koper/Capodistria was against the construction of any gas terminal in the Gulf of Trieste), and since Croatia also planned to realise a similar project on the existing oil terminal on the island of Krk near Rijeka with the assistance of a German investor.

On the other hand, at the European level aims for searching 'alternative' energy sources to the Russian gas became quite weaker after the political crisis in the southern Mediterranean, the completion of North Stream, namely the new sub-sea pipeline in the Baltic, which has since the end of 2011 directly connected Russia and Germany, and the intensification of the preparations for the construction of South Stream, which 
would supply gas across the Black Sea and the Balkans to Italy and Austria. After the catastrophe in Fukushima, the concern for possible consequences caused by an explosion of a gas terminal is also increasing and the new Italian government, facing the domestic financial issues, appears to be much more reluctant in supporting the previous investment plans, although the Ukrainian crisis has significantly slowed down the cooperation between the EU and Russia, thus re-opening again the 'energy issue' in Europe. However, due to higher expected costs, delayed administrative procedure, ecological and general endangerment as well as a modified global energyrelated context, now related in particular to cheaper oil offer, Italy has given up on the construction of the second gas terminal near Brindisi, and the central authorities do not show a particular interest for a similar object in the Gulf of Trieste, which is additionally 'burdened' by both the negative opinion of the local authorities and the neighbouring country, and thus consequently by the 'involvement' of European officials. Nevertheless, the prospected withdrawal of the project should not be explained with the 'failure' of any possibility for cross-border agreements and cooperation, since this would be quite a bad instruction for the future and for the implementation of joint and sustainable forms of planning in the Adriatic region.

\section{Conclusions}

Cross-border policies are most likely the most visible expression of the new management and planning system, which gradually evolved within the scope of the EU. In this 'Europeanisation' process of spatial and development policies, new institutional structures and ties that by necessity cross state borders and erase traditional hierarchies in the decision-making process, have emerged. According to some authors (e.g. CAstells 1998), a new, post-modern socio-political 'network' structure or authority is being formed, which is then expressed in the system of the so-called 'multi-level governance', where the sub-state dimension joins the inter- and supra-state integration dimension. The first dimension is somehow personified by the European Council, the second by the European Commission and the European Parliament, and the third by different Euroregions and cross-border associations of regions and local authorities. Within such a context, the Interreg programme functions as an actual possibility of implementing a multi-level network of governance, and can be regarded as a 'success story' of European integration policies in the field. This project-oriented cross-border cooperation and integration is also a reflection of a typical European practice that on the one hand boosts different pragmatic 'Eurocratic' agencies and committees, and on the other hand new and unimagined development scenarios and 'visions' for the future. The latter are mostly a subject of the European Spatial Development Policy, which, however, has to constantly cope with various development and spatial regulations since the perspective of the 'open' European social and planning area is still divided 
into 'closed' and fragmented national and sub-state systems that, after all, get their meaning in the very European principle of subsidiarity.

In any case, changes in the function and status of different territorial units and levels lead to changes in the function and status of their borders, which in today's Europe mostly move in the continuum between socio-cultural divergence and socioeconomic integration. It is this relationship that gives rise to major problems in relation to cross-border cooperation, as one could find here a considerable discrepancy between expectations and needs of the local population, and the real practice of cross-border policies. Communities on both sides of the border are simultaneously spatially divided and socially connected: spatial division is mostly dependent on the typology of the border regime, or (in the case of the Schengen space) rather on the harmonisation of development plans, which can pose major or minor obstacles to cross-border movements and activities, while social connection depends on the level of sociocultural homogeneity and better or worse functional integration of both the borderland population and space. The term cross-border cooperation itself presupposes that there exists a certain 'obstacle', that is the border, that has to be overcome, while the term social and spatial (re)integration calls for complete removal of the 'obstacle' (Houtum \& Struever 2002). In such a context, analysts of border situations and potentials of cross-border co-dependence have to consider both the symbolic and functional nature of this 'obstacle' since it can be established that it is precisely because internal borders no longer function as functional obstacles in the EU that they increasingly assume the role of symbolic, mental borders, which can become, again, a real obstacle to actual (re)integration of the border area and society. Borders therefore everywhere 'produce' environments of simultaneous potential opportunity or danger, contact or conflict, cooperation or competition, convergence or divergence (BUFON 2014).

The case discussed shows the need for a more appropriate governance of different horizontal (spatial and sectorial) as well as vertical (hierarchical) policies in planning cross-border cooperation or social and spatial (re)integration of borderlands and population, especially if we try to create a more sustainable and long-lasting development plan for our increasingly globalised and co-dependent 'common home'.

\section{References}

Bufon M. (2003), Cross-border cooperation in the Upper Adriatic. In: Anderson J. et al. (eds.), New Borders for a Changing Europe, pp. 177-196. London, Frank Cass.

Bufon M. (2008), Slovenska obmejna območja pred izzivi evropskega povezovanja. Koper, Založba Annales.

Bufon M. (2009), Zgornji Jadran: prostor konflikta ali koeksistence? In: Annales, 19, 2, pp. 457-468. 
Bufon M. (2011a), Cross-border policies and spatial and social integration: between challenges and problems. In: European Spatial Research and Policy, 18, 2, pp. 29-45.

Bufon M. (2011b), "Ne vrag, le sosed bo mejak!" - Upravljanje integracijskih procesov v obmejnih območjih. Koper, Univerzitetna založba Annales.

Bufon M. (2012), The changeable political map of the Upper Adriatic region between conflict and coexistence. In: Jordan P. (ed.), Regional Development and Regionalisation in the Adriatic Space, pp. 11-26. Wien, Verlag der Österreichischen Akademie der Wissenschaften.

Bufon M. (2013), Cross-border aspects of sustainable development in the Adriatic region. In: International Journal of Euro-Mediterranean studies, 5, 2, pp. 121-132.

Bufon M. (2014), Spatial and social (re)integration of border and multicultural regions: creating unity in diversity? In: Bufon M., Minghi J., PaAsi A. (eds.), The New European Frontiers - Social and Spatial (Re)Integration Issues in Multicultural and Border Regions, pp. 2-23. Newcastle Upon Tyne, Cambridge Scholars Publishing.

Bufon M., Minghi J. (2000), The Upper Adriatic borderland - from conflict to harmony. In: GeoJournal, 52, 2, pp. 119-127.

CAstells M. (1998), The Information Age - Economy, Society and Culture. Vol. III - End of Millennium. Oxford, Blackwell.

European Commission (ed.) (2010), Proposal for a Council Decision COM (2010) 30 final. Brussels, EC.

Houtum H., Struever A. (2002), Borders, strangers, doors and bridges. In: Space \& Polity, 6, 2, pp. 141-146.

KLEMENČIČ V., Bufon M. (1991), Geographic problems of frontier regions - the case of the ItaloYugoslav border landscape. In: Rumley D., Minghi J.V. (eds.), The Geography of Border Landscapes, pp. 86-104. London, Routledge.

LANGeR J. (2007), Euroregions - benevolence or deception? In: LANGer J. (ed.), Euroregions: The Alps-Adriatic Context, pp. 9-27. Frankfurt, Peter Lang.

Macrory R., Turner S. (2003), Cross-border environmental governance and EC law. In: Anderson J. et al. (eds.), New Borders for a Changing Europe, pp. 59-87. London, Frank Cass.

Parteka T. (2006), South Baltic Development Zone - Contribution to European Union cohesion. In: Palmowski T. (ed.), Baltic Europe - From Idea to Reality, pp. 93-104. Gdynia, University of Gdansk.

Scott J.W. (2003), Cross-border governance in the Baltic Sea Region. In: Anderson J. et al. (eds.), New Borders for a Changing Europe, pp. 135-153. London, Frank Cass.

Sсотт J.W. (2006), Wider Europe: geopolitics of inclusion and exclusion at the EU's new external boundaries. In: ScotT J.W. (ed.), Enlargement, Region Building and Shifting Borders of Inclusion and Exclusion, pp. 17-34. Aldershot, Ashgate.

Valentin H. (2007), Strategies and perspectives of the Alps-Adriatic Working Community. In: LANGER J. (ed.), Euroregions: The Alps-Adriatic Context, pp. 113-127. Frankfurt, Peter Lang. 